\title{
作物の蒸発散に関する研究
}

\section{（1） 水田蒸発散の季節・品種別特性と簡易推定法}

\author{
桜谷哲 夫 $^{*}$ 堀江 武* \\ $\left(\begin{array}{c}* \text { 九州農業試験場畑作部 } \\ * * \text { 京都大学農学部 }\end{array}\right)$
}

Studies on Evapotranspiration from Crops

(1) On Seasonal Changes, Varietal Differences and

The Simplified Methods of Estimate in

Evapotranspiration of Paddy Rice

Tetsuo SAKURATANI* and Takeshi HoRIE ${ }^{* *}$

$\left(\begin{array}{l}* \text { Laboratory of Meteorological Disaster, Kyushu Natl. Agric. } \\ \text { Exp. Stn., Yokoichi-cho, Miyakonojo 885, Japan. } \\ \text { ** Faculty of Agriculture, Kyoto University, Kyoto 606, } \\ \text { Japan. }\end{array}\right)$

\section{1.はしがき}

最近，農業生産を維持しつつ，さらに水を有効に利用 するための方策の研究に対して従来以上に大きな期待が 寄せられている。それは，近い将来，農業用水之民生用 水之の競合の増加が懸念されるうえ，水源から遠く隔た った地帯への農耕地拡大の要求が高まってきているとと による。乙れを背景に，作物の生産と水利用に関する研 究が畑・水田作を問わず活発になされている。乙れらの 広範な研究を推進するうえで, 耕地蒸発散と作物・気象 要因との関係解析，および蒸発散の推定法の開発は重要 な位置を占める。

本報告で対象とした水田の蒸発散特性に関して，我国 では 1950 年代以降数多くの研究成果が蓄積されている。 すなわち，1950～60 年代には，水田蒸発散量の測定が 各地でなされるとともに，気象条件との関係が明らかに され(たとえば，羽生・小野，1960；佐藤，1960)水利 用計画などに広く利用された。1960 年代以降は，接地 気層の物理学と測定器の進歩に伴って, 水田の水・熱収 支機構が研究され (Iwakiri， 1965; 蒸発散研究グルー プ，1967B； Seo and Yamaguchi，1968)，その成果 が水田蒸発散量のより精密な推定法の開発に利用されて いる。

てのように, 多くの成果が提出されているが, 水田に 昭和 58 年 4 月 7 日 全国大会にて発表 昭和 60 年 2 月 20 日 受理
おりるより効率的な水利用を図るためには，まだ未解決 な問題が若干残されている。その第一は，水田蒸発散が 気象要因によってのみ支配されているのか，あるいは気 象要因と生育ステージの両方によって支配されているの かという問題である。乙の点にまで言及した報告は我国 ではあまり見あたらないようである。

第二に，超多収穫稲が我国に導入されているが，我国 で外国稲の蒸発散特性を研究した例が少ないととであ る。外国稲の導入拡大を図るための基礎として，外国稲 と日本稲の蒸発散特性の差異を解明しておくことが重要 である。

そして第三に，水田蒸発散の推定法の確立である。作 物蒸散は物質生産之密接に関係しているととが知られて いる。水稲においても, 水田蒸発散や作物蒸散とバイオ マスや収量との間に高い相関関係のあることが明らかに されてきた(杉本, 1975 ; Shih et al., 1983)。蒸発散 の推定は，用水量の決定のみならず，乙のような生産予 測においても必要とされている。蒸発散量の推定法とし て従来より種々な方法が提案されているが，簡易で精度 の高い方法の開発が望まれている。

本研究は, 以上のような背景のあとに, (1)水田蒸発散, イネ個体群蒸散および水面蒸発の季節変化の解明, (2)日 本稲と外国稲の蒸発散特性の差異の解明，(3)水田蒸発散 の簡易推定法の確立，を目的としたものであり，一応の 結果を得たので報告する。 


\section{2. 研究方法}

\section{1 固 場}

蒸発散の測定を, 既報 (堀江・桜谷, 1985) の研究の 一環として, 筑波の農業技術研究所構内に 1982 年に設 定した試験区に㨟いてミクロライシメータによって行っ た。試験区の構成とイネの栽培条件については既報(堀 江・桜谷，1985）に詳述してあるが，本稿を理解するた めに必要な事項について以下に略記しておく。

試験戋場を，作期を異にする区と品種を異にする区よ り構成した。前者には, 品種「日本晴」を, 3 月 31 日 移植日を第 1 作期区 (N1) とし， 7 月 5 日移植日を第 8 作期区 (N8) とする 8 作期で栽培した。これによって, 4 月から 10 月までの幅広い気象条件下で蒸発散を測定 するととができた。後者には, 日印交配品種の「密陽 23 号」とインド型の「IR-36」を日本晴の 5 番目の作期 (N5) と同様の作期 (5 月 24 日移植) で栽培した。この外 国稲 2 品種と N 5 の水田面積はそれぞれ $500 \mathrm{~m}^{2}$ であっ た。他の試験区の面積はすべて $40 \mathrm{~m}^{2}$ であった。これら の試験区は 4 ha の水田圃場内に設定されたので主要生 育期間には試験戋場周囲からの移流の影響は小さかった あのとみられる。

\section{2 測定方法}

本実験で用いたミクロライシメータは，Tomar and O’ Toole (1980 A) が用いたあのと基本的に同じであり, 面積 $600 \mathrm{~cm}^{2}$, 深さ $60 \mathrm{~cm}$ の有底ステンレスパンと水位 を拡大して測るマリオット管より構成された（堀江・桜 谷, 1982)。

試験区の耕起後， 1 試験区につき 3 台のパンを， 1 台 を試験区中央に，他の 2 台を， $40 \mathrm{~m}^{2}$ の試験区では中央 のパンの左右 $1 \mathrm{~m}$ の点(長辺に平行) に, $500 \mathrm{~m}^{2}$ の試験区 では同様に $10 \mathrm{~m}$ の点に埋設した。このとき堀り取った 土壤をできるだけ土層を擋乱しないようにパンに充填し た。水面蒸発量測定用として用いた中央のパンを除く 2 台のパンには，各試験区への田植時にイネを 2 株（1株 3 本植)ずつ移植した。 3 台のパンとも水深が $3 \sim 4 \mathrm{~cm}$ となるようにマリオット管の高さを調節した。

マリオット管の水位を毎朝 9 時に読取り, 前日の同時 刻における水位との差にマリオット管とパンの面積比を 乗じた值を前日の蒸発(散)量とした。前日 9 時から当日 9 時の間に降水があった場合でも，マリオット管の水位 が低下していたときは上と同様にして求めた值を前日の 蒸発(散) 量とした。水位に変化がみられなかったときに は前日の蒸発 (散) 量を 0 とした。従って, 雨天日の蒸発 (散) 量にはある程度の誤差を含んでいたあのとみられ る。2 台のパンの平均值を水田蒸発散量とし, 蒸散量は
蒸発散量之水面蒸発量の差加求めた。

純放射とアルベドを，N1，N4，N5 およびN7 の植被 上約 $1 \mathrm{~m}$ の高度で，それぞれ風防型純放射計とゴルチン スキー日射計を用いて測定した。水田の気温と湿度は $\mathrm{N} 1$ に設置した熱電対通風乾湿計（地上高 $1.5 \mathrm{~m}$ ) により 求めた。日射量と風速は, 試験圃場から約 $300 \mathrm{~m}$ のとて ろにある観測露場での測定值を使用した。

\section{3 基準蒸発散}

本稿では，蒸発散に及ぼす生育ステージの影響を調べ るにあたり, 蒸発散と基準蒸発散との比を求めて気象 条件の影響を消去しようとした。ここで, 基準蒸発散 $(E T R)$ は「水分欠乏のない生育の活発な草高 $8 \sim 15 \mathrm{~cm}$ の密生した広い牧草地加ら蒸発散」(Doorenbos and Pruitt，1977）之定義される。気候資料加らETRを求 めるために, Doorenbos and Pruitt (1977)は, 改良 Penman 法, 日射法, Blaney-Criddle 法および蒸発計 法の 4 つを提案している。Penman 法は水田蒸発散と高 い相関関係にあるてとが報告されているので（蒸発散研 究グループ，1967B)，本稿では上の 4 方法のうち次式 で示される改良 Penman法を用いた。

$$
E T R=c\left[\frac{\Delta}{\Delta+r} \frac{R_{n}}{L}+\frac{r}{\Delta+r} f(u)\left(e_{s}-e\right)\right]
$$

ここで， $R_{n}$ は純放射量 $\left[\mathrm{MJ} \cdot \mathrm{m}^{-2}\right], f(u)$ は風速の関数, $e_{s}$ は日平均気温に打ける飽和水蒸気圧 $[\mathrm{mb}], e$ は日平 均水蒸気圧 $[\mathrm{mb}], \Delta$ は日平均気温における飽和水蒸気 圧一温度曲線の傾度 $\left[\mathrm{mb} \cdot{ }^{\circ} \mathrm{C}^{-1}\right], r$ は乾湿計定数 $[\mathrm{mb}$. $\left.{ }^{\circ} \mathrm{C}^{-1}\right] ， L$ は蒸発潜熱 $\left[\mathrm{J} \cdot \mathrm{g}^{-1}\right], c$ は気候によって定まる 経験定数，そしてててでのETRの単位は $\mathrm{mm} \cdot \mathrm{day}^{-1}$ で ある。 $R_{n}$ と $f(u)$ は, Doorenbos and Pruitt (1977) に従って，それぞれ次式から求めた。

$$
\begin{aligned}
R_{n}= & (1-A) R_{s}-R_{l n} \\
& R_{s}=\left[c_{1}+c_{2}\left(\tau / \tau_{0}\right)\right] R_{0} \\
& R_{l n}=\sigma T_{a}^{4}\left(c_{3}-c_{4} \sqrt{e}\right)\left[0.1+0.9\left(\tau / \tau_{0}\right)\right] \\
f(u) & =0.27+0.233 u
\end{aligned}
$$

ここで， $A$ はアルベド， $R_{s}$ は日射量 $\left[\mathrm{MJ} \cdot \mathrm{m}^{-2}\right], R_{l n}$ は長波有効放射量 $\left[\mathrm{MJ} \cdot \mathrm{m}^{-2}\right] ， \tau$ は日照時間 $[\mathrm{h}] ， \tau_{0}$ は 可照時間 $[\mathrm{h}] ， R_{0}$ は大気圈外日射量 $\left[\mathrm{MJ} \cdot \mathrm{m}^{-2}\right] ， \sigma$ は Stefan-Boltzman 定数 $\left[4.90 \times 10^{-9} \mathrm{MJ} \cdot \mathrm{m}^{-2} \mathrm{~K}^{-4}\right], u$ は $2 \mathrm{~m}$ 高での日平均風速 $\left[\mathrm{m} \cdot \mathrm{s}^{-1}\right], c_{1}, c_{2}, c_{3}, c_{4}$ は経 験定数である。本研究では， $A$ の値として $0.25 を ， c_{1}$ と $c_{2}$ の值としてそれぞれ 0.25 と 0.50 を，湿潤地帯の $c_{3}$ と $c_{4}$ の值としてそれぞれ 0.56 と 0.079 を用いた。我国 の気候条件を考慮し (1) 式中の $c=1.0$ 之仮定した。 


\section{3. 結果}

\section{1 葉面積指数とアルベド}

日本晴の各作期に㧍ける葉面積指数 (LAI)の推移が 既報(堀江・桜谷, 1985)の Fig. 2 亿示されている。乙 れを後述の蒸発散の推移と対比させるために再掲載した のが Fig. 2 B のハッチの部分である。LAI は出穂期でろ 最大となっており, 移植後最大に達するまでの所要日数 は移植期が遅いほど短くなっている。てれはあとの作期 ほど高温下で栽培されたため生長が促進されたてとによ る。最大LAI はあとの作期ほど小さくなる傾向にあり， N1〜N4 は約 6 であったがN5〜N8 は約 5 であった。

N1，N4 およびN5に扑てて得られたLAI とアルベド との関係を示したのが Fig. 1 である。アルベドの変化パ ターンに作期による明瞭な差は認められず，いずれあ LAI の小さい領域 (0〜3)では急激に増加し, LAIが約 3 以上では増加が鈍化している。図中の実線は, 蒸発散 研究グループ $(1967 \mathrm{~A})$ が提出した次式を，パラメータ $A_{f}=0.21, A_{0}=0.07, k=0.50$ として描いたあのである。

$$
A=A_{f}-\left(A_{f}-A_{0}\right) \exp (-k F)
$$

ここで, $A_{f}$ と $A_{0}$ はそれぞれ地面が完全に植被で覆われ たときと植被のないときの反射率， $F$ は葉面積指数， $k$ は減衰係数である。各測点は打打むねての曲線の周囲に 分布し，LAI とアルベドとの関係は(4)式によって良 く表わされることが確かめられた。上の各パラメータの 值は既報（堀江・桜谷，1985)で得られた值にきわめて 近い。

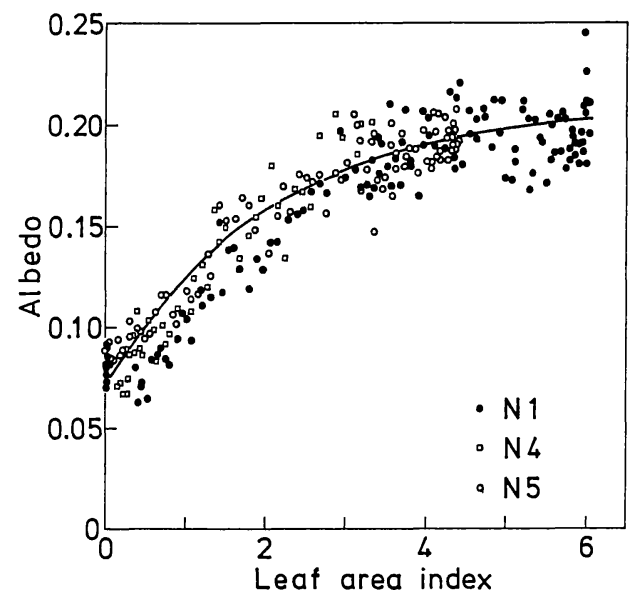

Fig. 1. Dependence of albedo on leaf area index (LAI) for "Nipponbare" rice grown in three different cropping seasons.

\section{2 蒸発, 蒸散, 蒸発散の季節変化}

\subsection{1 水面蒸発}

日本晴の各作期における水田植被下の半旬平均水面蒸 発量 $(E)$ の推移を示したのが Fig. $2 \mathrm{~A}$ の点線である。 LAI の小さい生育初期には， $E$ の值が天候によってか なり大きく変動しているが, 最大值は約 $6 \mathrm{~mm} \cdot$ day $^{-1}$ に 達している。乙の值は盛夏期の蒸発散量 $(E T)$ に匹敵し ているのが注目される。N1のように初期生育が長期に わたる試験区では， $E$ が $E T$ の大部分を占める期間が 1 力月近くに達している。LAI の増加につれて $E$ は減少 し， LAI の最大期頃には $E T$ の中で $E$ の占める 割合は $10 \%$ 程度となっている。

気象条件の影響を消去するために, $E / E T$ を求めた。 同一LAI で $E / E T$ 亿作期による差異は認められなかっ た。そてで，全作期の $E / E T$ について，LAIの $1.0 の$ 幅でグルーピングして平均值と標準偏差を計算した。そ の結果を Fig. 3 亿示す。測点の変動はやや大きいが, LAI が約 3 まではLAIの増加につれて E/ETは急激に 減少し，LAIが約 3 以上では減少が鈍化している。LAI とE/ET との関係は，Uchijima (1961) および岩切 (1964)が提案した次式によってよく表わされた。

$$
\frac{E}{E T}=e^{-k F}
$$

ここで， $F$ は葉面積指数である。パラメータ $k$ は本実験 では 0.40 となり，岩切(1964)の得た值(0.44)に近かっ た。

\section{2 .2 蒸 散}

個体群蒸散量 $(T)$ の生育に伴う推移が Fig. 2 A 亿細い 実線で示されている。TはLAI の増大に伴って増加し， LAI の最大期でろにはETの約 $90 \%$ までに達した。移 植期の遅い程，田植直後からの $T$ の増加が急になってい る。乙れは，前述のようにあとの作期ほどLAI の増加 が急なためである。

上と同様にして $T / E T$ とLAI との関係を求めた。そ れがFig. 3 に示されている。E/ET とは全く逆に最初は 急激にあとは綅や汃に増加している。両者の関係は次式 で表わされた。

$$
\frac{T}{E T}=1-e^{-0.40 F}
$$

\subsection{3 蒸発散}

$E$ とTの合計值である水田蒸発散 $(E T)$ の推移を Fig. $2 \mathrm{~A}$ に太い実線で示してある。全生育期間を通してみる と，ETは生育ステージとは無関係に天候によってのみ 影響されながら推移しているようにみえる。8 作期のう ち最も長期の測定がなされた N1 亿着目すると，ETの 最大は 5 月に現われており，盛夏期の 7〜8月はやや小 


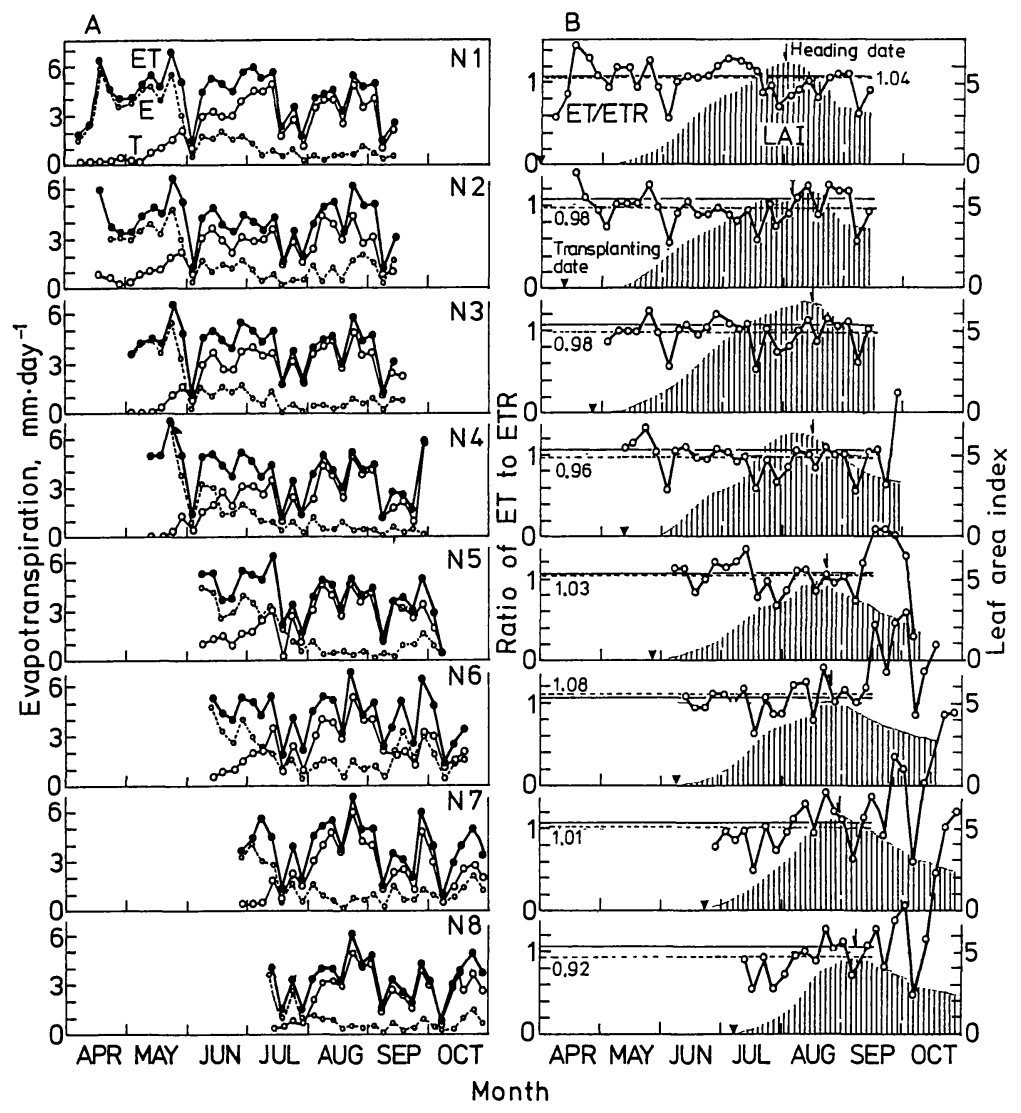

Fig. 2. (A) Seasonal change of evaporation $(E)$, transpiration $(T)$ and evapotranspiration $(E T)$ from paddy fields for "Nipponbare" rice grown in eight different cropping seasons (five-day mean).

(B) Seasonal change of LAI and the ratio of ET to reference $E T(E T R)$ for "Nipponbare" rice grown in eight different cropping seasons.

Note: Broken lines and numerals in the figure represent mean value of daily $E T$ for main growth period (transplanting date - mid-September), and straight lines the mean value (1.05) of daily $E T$ for eight cropping seasons.

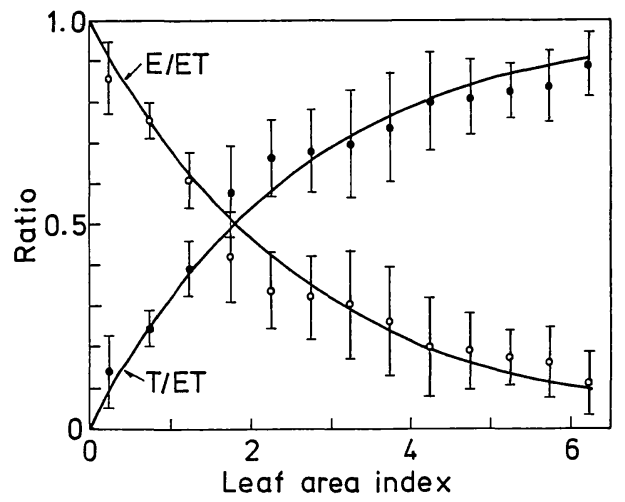

Fig. 3. Dependence of $E / E T$ and $T / E T$ on LAI for "Nipponbare" rice grown in eight different cropping seasons.

Note: Bars in the figure represent standard deviation. 
さい値となっている。てれは，1982 年は 5 月に晴天日 が多く，7〜8月が天候不順であったてとに起因する。

天候の影響を消去するために，基準蒸発散 $(E T R)$ に 対する $E T$ の比 $(E T / E T R)$ を求め図示したのがFig. $2 \mathrm{~B}$ の実線である。図中の点線は，各作期における測定開始 日から9月 15 日までの測点の平均值を表わし, 直線は 全作期をてみにした平均值 $(E T / E T R=1.05)$ を表わす。 図のように，各測点は，9月中旬でろまでそれぞれの平 均值の周囲に分布し，絶対值の推移加予想されたよう に，LAI や季節とは全く無関係に推移している。しか し， 9 月第 4 半旬以降 $\mathrm{N} 4 \sim \mathrm{N} 8$ において ET /ETRに加 なり大きな值が出現した。これは，あとに述べるように， 乙の時期の $E T R$ の過小評価と移流の影響が原因してい るように見受けられる。

\section{3 蒸発, 蒸散, 蒸発散の総量}

田植直後から成熟期までの水面蒸発，個体群蒸散およ び水田蒸発散の総量が Table 1 亿示されている。蒸発総 量 $\left(\sum E\right)$ は移植期が早いほど多い傾向にあり, N1 が $320 \mathrm{~mm} / 162$ day であったのに対し, N 8 ではその $37 \%$ の $118 \mathrm{~mm} / 120$ dayであった。乙れは，早い作期ほど気 温が低いため LAI の增加が遅れ，その間，水面蒸発が 卓越したためである。蒸散総量 $\left(\sum T\right)$ は $\sum E$ と同様の傾 向にあるが, その範囲は $\mathrm{N} 1$ の $360 \mathrm{~mm} / 162$ day から $\mathrm{N} 8$ の $296 \mathrm{~mm} / 120$ day と $\sum E$ ほど差が開いていない。 $\sum E$ $+\sum T$ で表わされる蒸発散総量 $\left(\sum E T\right)$ 屯当然あ之の作 期ほど少ない傾向を示し， N1 の $680 \mathrm{~mm} / 162$ day から $\mathrm{N} 8$ の $414 \mathrm{~mm} / 120$ day そと変化している。

全生育期間 1 日あたり蒸発散量は, N8 が $3.5 \mathrm{~mm}$ とや や少なかった以外は作期による傾向はみられず，3.9〜
$4.2 \mathrm{~mm}$ の間にあり, 8 作期の平均では $4.0 \mathrm{~mm}$ となった。 Tomar and O'Toole (1979)は, アジア各地で得られ た水田蒸発散の值を整理し， 日本については 4.4 5.5 $\mathrm{mm}$ の範囲にあったと報告しているが, 著者らの $4.0 \mathrm{~mm}$ という值はてれよりあ10～30\%小さい，また，著者ら の值は彼らの報告には含まれていない蒸発散研究グルー プ(1967B)の值 (3.1 mm) および Iwakiri (1965)の值 $(3.7 \mathrm{~mm})$ よりもそれぞれ $29 \%$ および $8 \%$ 大きく，宮本・ 日野 (1979) の関東地方南部に扔ける推定值に非常に近 い。

\section{4 品種と蒸発散}

外国稲之日本晴の蒸発散特性の差異を調べるために, Fig. 2Bにならって, 密陽 23 号と IR-36 のET/ETR を計算した。その結果がFig. 4 亿示されている。図にみ られるように，乙れら 2 品種のET/ETRは, N5 (Fig. $2 \mathrm{~B})$ と同様，9月中旬までは比較的小さな変動で推移し ている。しかし，詳細にみると両品種とも LAI の最大 期頃に弱いピークが認められる。てれはN5 では認めら れない現象である。田植直後から 9 月 15 日までの $E T /$ $E T R$ の平均值も N5 亿比べ密陽 23 号で $7.8 \%$, IR-36 で $10.7 \%$ 大きい值を示した。

外国稲 2 品種の $E T$ が LAI 最大期頃にピークをむつ理 由としてTの增加が予想された。そてで，晴天日（日射 量 $20 \mathrm{MJ} \cdot \mathrm{m}^{-2}$ 以上) に打りる $T / E T R$ を求め，LAI と の関係で表わしてみた。それがFig. 5 である。LAIが 2 以上の領域に注目すると, 日本晴では比較的測点の変動 が小さいのに対し, 外国稲 2 品種はかなり変動が大きく, 日本晴の $1.4 \sim 1.8$ 倍の範囲にまで測点が分布している。 これは外国稲 2 品種の蒸散量が増加しやすい性質をむっ

Table 1. Total amounts of evaporation $\left(\sum E\right)$, transpiration $\left(\sum T\right)$, evapotranspiration $\left(\sum E T\right)$, the ratio of $\sum E$ to $\sum E T$ and mean value of daily $E T$ for total growth periods from transplanting to ripened date of each "Nipponbare" rice grown in eight different cropping seasons.

\begin{tabular}{cccccccc}
\hline Notation & $\begin{array}{c}\text { Transplant } \\
\text { date }\end{array}$ & $\begin{array}{c}\text { Ripened } \\
\text { date }\end{array}$ & $\begin{array}{c}\text { Evaporation } \\
\sum E, \mathrm{~mm}\end{array}$ & $\begin{array}{c}\text { Transpiration } \\
\sum T, \mathrm{~mm}\end{array}$ & $\begin{array}{c}\text { Evapotran- } \\
\text { spiration } \\
\sum E T, \mathrm{~mm}\end{array}$ & $\begin{array}{c}\sum E / \sum E T \\
\text { Mean value } \\
\text { of daily } \\
E T, \mathrm{~mm} \mathrm{day}^{-1}\end{array}$ \\
\hline N1 & $31 / \mathrm{II}$ & $12 / \mathrm{X}$ & 320 & 360 & 680 & 0.47 & 4.2 \\
$\mathrm{~N} 2$ & $12 / \mathrm{N}$ & $14 / \mathrm{X}$ & 272 & 350 & 622 & 0.44 & 4.0 \\
N3 & $26 / \mathrm{N}$ & $19 / \mathrm{X}$ & 232 & 358 & 590 & 0.39 & 4.1 \\
$\mathrm{~N} 4$ & $10 / \mathrm{V}$ & $30 / \mathrm{X}$ & 214 & 348 & 562 & 0.38 & 4.0 \\
N5 & $24 / \mathrm{V}$ & $11 / \mathrm{X}$ & 212 & 306 & 518 & 0.40 & 3.9 \\
N6 & $8 / \mathrm{V}$ & $18 / \mathrm{X}$ & 236 & 314 & 550 & 0.43 & 4.2 \\
N7 & $21 / \mathrm{V}$ & $25 / \mathrm{X}$ & 163 & 304 & 467 & 0.35 & 3.9 \\
N8 & $5 / \mathrm{VI}$ & $5 / \mathrm{XI}$ & 118 & 296 & 414 & 0.29 & 3.5 \\
\hline
\end{tabular}

Note: The number of days with missing data is 3 in N1 and N8, and 4 in $\mathrm{N} 5$ and $\mathrm{N} 7$. 


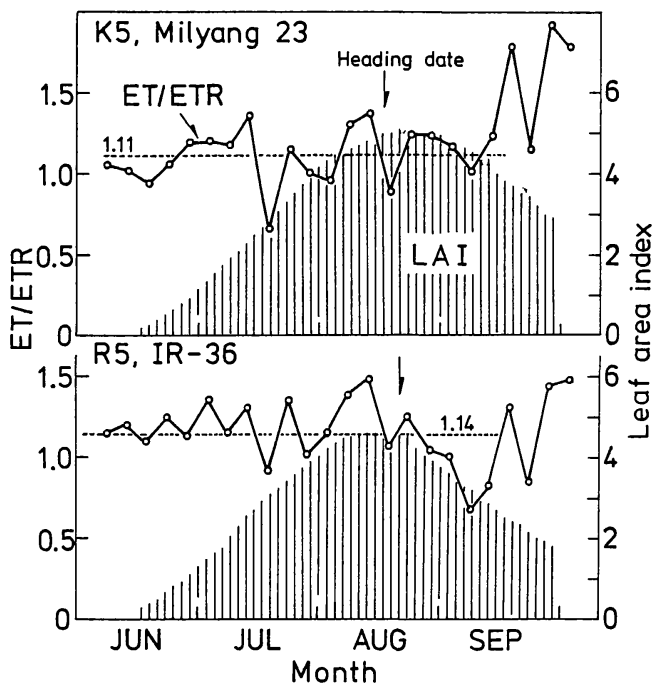

Fig. 4. Seasonal change of ratio of actual evapotranspiration to the reference one (ET) $E T R$ ) and LAI for "Milyang 23" and "IR-36".

Note: Broken lines in the figure represent mean value of ET/ETR for main growth period from transplanting date to mid-September.

ているためとみられるが，てれについては後で若干考察 する。

\section{5 蒸発散の推定法}

現在までのいくつかの研究において, Penman法は水 田蒸発散を推定するのにかなり有効であるととが明らか にされている(たとえば，蒸発散研究グループ，1967B)。 本研究においても，改良 Penman法を用いた基準蒸発 散に係数 1.05 を乗ずることによって水田の半旬蒸発散 量を相関係数 $0.878(n=183)$ で推定できた。しかし， Penman 法では純放射(または日照時間) と気温のほか, 風速と湿度のデータを必要とする。乙のため, その使用 がこれらの気象要素が観測されている地点に限られる。

日射法とPriestley-Taylor 法は, 用いる気象要素が 2 個でよいため, 適用条件と推定精度についてかなり研 究が行われている。しかし，我国の水田に対して，てれ らの方法を適用した例はみあたらない。以下では両方法 の筑波に抢ける水田への適用性を研究した。

\subsection{1 日射法}

日射法には 2〜3の方法があるが，乙てでは Makkink （1957）によって提案された次式を用いた。

$$
E T=a \frac{\Delta}{\Delta+r} \cdot \frac{R_{s}}{L}
$$

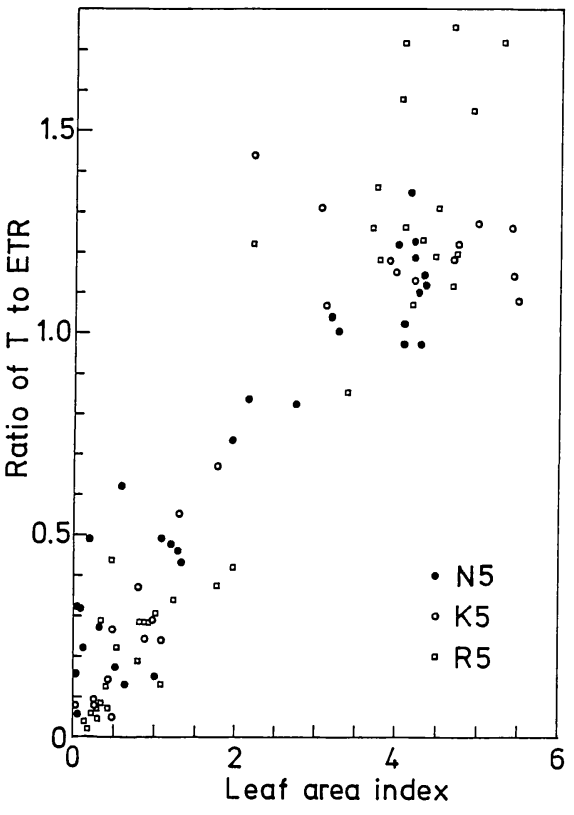

Fig. 5. Ratio of the daily transpiration to the reference evapotranspiration $(T / E T R)$ in clear days (solar radiation $\geq 20.0 \mathrm{MJ} \mathrm{m}^{-2}$ ) as a function of LAI, for three rice cultivars of "Nipponbare" (N5), "Milyang 23" (K5) and "IR-36" (R5).

こてで， $a$ は経験定数である。本実験では $a$ がミクロラ イシメータ蒸発散量と日射量および気温から求められ た。乙の毎日の推移が Fig. 6 に示されている。ただし， $E T=0$ のときの $a$ 值 $(=0)$ は除外してある。また,$a$ 值 はN1〜N8のすべての作期について求められたが, 各作 期において傾向が似ているととと, 次に述べる Priestley-Taylor 法の経験定数 $\alpha$ との比較のために，N1， N5, N7 に限って示してある。眓の上うに，aの変動は 比較的小さく, 変動係数は 27〜35\%であった。特にN1 では, 生育期間を通し, 平均值 $\bar{a}=0.93$ の周囲に各測点 がほぼ均一に分布している。N5 とN7 においては，9 月中旬から 10 月にかけて測点の変動が大きくなってお り，aが若干過大評価されている。てれは，登熟期にお いてあ本試験圃場に限って水田状態を維持したため, 周 囲からの比較的乾燥した空気の移流によって蒸発散が増 加したためと思われる。

移流の影響が少ないとみられた移植期から9月中旬ま での期間における全作期のデータを回帰分析し， $\bar{a}=0.88$ が得られた。乙の值を用いて，(7)式から半旬平均蒸発 散量が相関係数 $r=0.912(n=183)$ で推定された。この $r$ の值は改良Penman 法よりもやや高い。日射法の有効 性については, 我国では矢野ら（1977）が牧草地で確か 


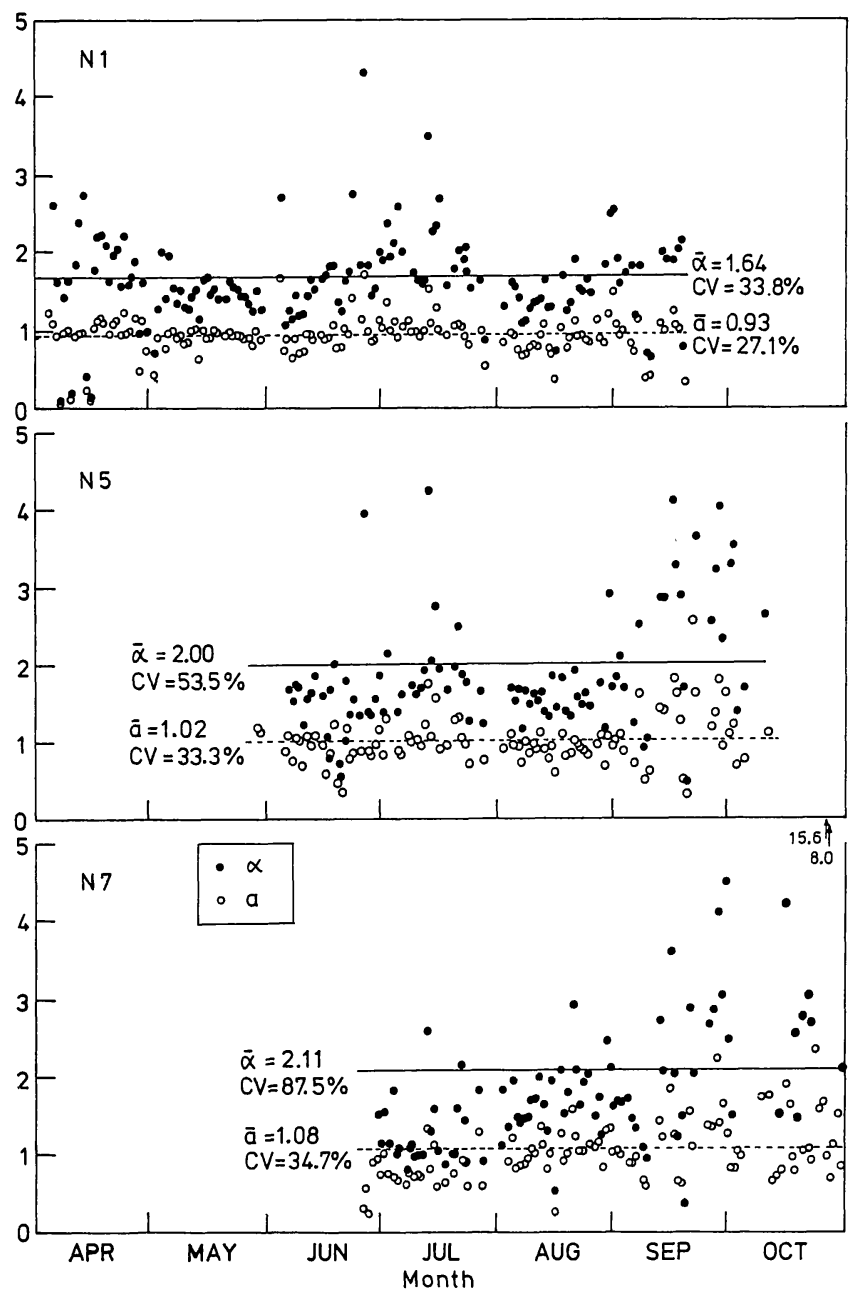

Fig. 6. Seasonal change in daily values of $a$ in Eq. (7) and $\alpha$ in Eq. (8), for "Nipponbare" rice grown in three different cropping seasons.

Note: $\bar{a}$ and $\bar{\alpha}$ represent respectively mean value of $a$ and $\alpha$ for total growth periods, and $C V$ refers to the coefficient of variation. $\alpha$ が純放射の実測值を用いて計算され た。ての結果がFig.6亿示されている。図 より明らかなように， $\alpha$ の值は各区共にか なり大幅に変動している。特に, N5 と N7 にみられるように，9月と10月の変動が 大きく， N7 では $\alpha=15.6$ 亿達した日があ った。てのため変動係数はN7で $88 \%$ と非 常に大きな值となった。一方，全生育期間 の $\alpha$ の平均は N1，N5，N7でそれぞれ 1.64, 2.00, 2.11 であった。特に変動の大きい 9 月中旬〜10月の值を除いて計算しても， N5 と N7 の $\alpha$ はそれぞれ 1.73 および 1.57 となり, Priestley and Taylor (1972)の 提案した值(1.26)よりむ 25〜37\%大きい。 Pruitt and Doorenbos (1977)は, $\alpha$ が 気候帯によって 1.21〜2.0 の範囲をとるこ 之を見出している。本実験では $\alpha か ゙$ 時期に よってあかなり大幅に変化することが確か められ， $\alpha=$ 一定として (8) 式を適用する ことに限界があることがわかった。

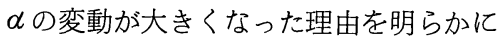
するために次の解析を行った。（7）式之 (8)式から

$$
\alpha=a \cdot\left(\frac{R_{n}}{R_{s}}\right)^{-1}
$$

上式より明らかなように， $R_{n} / R_{s}$ が一定 ならば，Fig. 6 の $\alpha$ とは一定の比率を 保って変化するはずである。実際にはその 上うな関係が明瞭でないのは $R_{n} / R_{s}$ が変 化しているととを意味している。乙の変化 とそ机伴う $\alpha$ の変化が Fig. 7 に示されて いる。図中の実線は，N1，N5，N7 の全 生育期間に拈ける $a$ の平均值 $(\bar{a}=1.0)$ であ る。図の上うに, $R_{n} / R_{s}$ は 0.4 0.8 の間 に変化しており， $R_{n} / R_{s}$ の減少に伴って
めている。

\subsubsection{Priestley-Taylor 法}

Priestley and Taylor (1972)は, 純放射と気温か ら広い湿面の蒸発散量を求めるための次式を提案した （ただし，原式では地中伝導熱量 $(G)$ が付加されている が，日量を対象とした本稿では $R_{n} \gg G$ 之仮定し， $G$ を無 視した)。

$$
E T=\alpha \frac{\Delta}{\Delta+\gamma} \cdot \frac{R_{n}}{L}
$$

ここで， $\alpha は$ 経験定数で Priestley and Taylor (1972) は $\alpha=1.26$ を提案している。 $\alpha$ の増加傾向が認められる。特に, $R_{n} / R_{s}$ の $0.6 \sim 0.8$ の範囲では, 測点が $\bar{a}=1.0$ の周囲に分布し，(9)式の関 係がほぽ満たされている。

$R_{n} / R_{s}$ が変動する条件は一般的に次の式から見出す ことができる。

$$
\frac{R_{n}}{R_{s}}=(1-A)-\frac{R_{l n}}{R_{s}}
$$

ここで， $R_{l n}$ は長波有効放射である。 $A$ と $R_{s}$ とを一定 とすれば， $R_{n} / R_{s}$ は $R_{l n}$ によって変動する。中山・中 村 (1982) は大根畑における $\alpha$ が 10〜11月に大きな值を 示し, 変動も大きくなることを報告している。そして, 


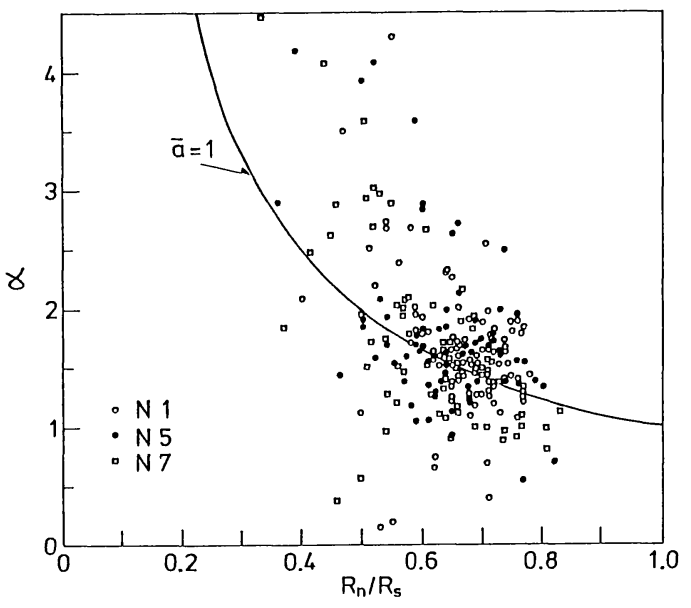

Fig. 7. Relation between $\alpha$ of Priestley-Taylor equation and the ratio of daily net radiation $\left(R_{n}\right)$ to solar radiation $\left(R_{s}\right)$.

これは純放射日量が夜間の長波有効放射の增減によって 大きく変動するためであるてとを見出している。また， 昼間の純放射量を用いると $\alpha$ の変動はかなり小さくなる ことも明らかにしている。本実験の場合屯, 昼間の純放 射量に基づく $\alpha$ の $C V$ は， N1，N5，N7亿扔いて，それ ぞれ，30.0，38.6，39.4\%となり，日射法の $C V$ (Fig.6) に及ばないあのの, かなりの低下がみられた。

以上のととから， $\alpha$ の值が大きく変動するのは，主と して夜間の長波有効放射の増減に原因していると結論さ れる。

\section{4. 考察}

水田の $E T / E T R$ を変動させる要因として植被の粗 度と気孔抵抗などをあげることができる（Tomar and O’Toole, 1980B)。乙のうち, 水田の粗度はイネの生 育によってかなり変化する (Seo and Yamaguchi, 1968)。また井上ら (1984) は水田植被の平均気孔抵抗 が生育時期によって変動するととを見出した。一方, LAI の増加は水田植被面のアルベドを増大させる (Fig. 1)。乙のように，イネの生育に伴って作物要因が変化す るにもかかわらず， 日本晴の ET / ETRが田植直後から 9 月中旬までほぼ一定の值で推移したということは，日 本晴の蒸発散量が気象要团によって大きく支配され，作 物要因の影響が小さかったてとを意味している。湿潤地 帯における草丈の低い植生加ら蒸発散は主として気象 要因, 特に純放射によって支配されており, 植物要因の 影響は比較的小さいといわれているが(Stuwart, 1983), このととが我国の日本稲水田にあ適用されることがわか った。
水田での $E T / E T R$ が生育期間中ほぼ一定の值をとる ことについて, Doorenbos and Pruitt(1979)は, 多 湿で弱風の地域で, 生育中期まで $E T / E T R=1.1$, 生育 後期に 0.95 となると報告している。乙れは著者らの求め た值 (1.05) にきわめて近い。一方, 蒸発散研究グループ (1967B)は，著者らの值より 11\%小さい 0.92 なる值を 提出している。乙の違いは，(1)式に含まれる $f(u)$ の 推定法の差異に起因するものと考えられる。

水田蒸発散関する既往の研究の多くは, 簡易な基準 值として蒸発計蒸発量 $(E P)$ を用い, $E T / E P$ の季節変 化を研究している。前出の蒸発散研究グループ (1967 B) は $E T / E P$ が生育前期から後期に向って単調に減少する ことを見出した。また逆に $E T / E P$ が生育初期から後期 にかけて単調に増加するという報告がある(たとえば， 佐藤，1960)。乙のように，ET/ETRが生育期間中ほ ぼ一定の值をとるのに対し， $E T / E P$ が単調な変動を示 す理由については更に研究が必要のように思われる。

上述の $E T / E T R \simeq$ 一定なる結果は日本晴において得 られたあのである。密陽 23 号とIR-36においてはLAI の最大期頃にET/ETR の弱いピークが認められた。そ して，乙れは蒸散量の増加によるあのであることがわか った。杉本 (1973)は, 日本稲とインド稲の蒸散量を比 較し, 単位葉面積当り蒸散量が日本稲よりインド稲がま さり, 特に高温下ではインド稲の蒸散量が著しく大きく なることを報告している。また，丸山ら(1984) あイン ド稲の要水量は日本稲よりも大きいととを見出してお り，それは葉身の気孔抵抗の差異によるあのと推論して いる。

本実験で外国稲 2 品種の ET / ETR がLAI 最大期頃に ピークを示したのは，上のような特性が LAI の大きい ときに強く現われたためであろう。熱帯や乾燥地帯では, $E T / E P$ が最高分けつ期と出穂期にピークをもつ双頂型 の変化を示すという報告(たとえば， Sugimoto，1971； Tomar and O'Toole, 1979)や出穂期にのみ最大值を とるという報告(たとえば, Chapman and Kininmoth, 1972 ; Shih et al., 1983)があるが，乙れは品種の特 性と無縁でないように思われる。

日射法が日本晴の水田蒸発散量の推定において良い結 果を得たのは, 日本晴がインド稲のように高温下であ蒸 散量が著しく増加しないととも原因の一つとして考えら れる。しかし，我国では牧草地においてあ日射法が良い 結果を得ているととから(疑ら，1977)，むしろ我国 の多湿な気候条件が日射法の適用性を有利なものにして いるとみるのが妥当であ万う。すなわち，前述のように， 一般に多湿な気候条件では，土壌水分が十分な場合，純 放射が蒸発散を大きく支配している。そして, 蒸発散日 
量とは，純放射日量よりあ昼間の純放射量との方が相関 が高い(中山・中村，1982)。一方，日射量は後者と高 い相関関係にある。

Priestley-Taylor法は, 湿潤な熱帯気候や (Gunston, 1983)，我国では牧草地に拀いて(中川，1982）良い結 果が得られている。しかし，本実験の結果では水田への 適用性が劣るととがわかった。この主な原因として, 純 放射日量が夜間の有効放射によって大きく変動するてと を指摘した。我国に扔いては，秋〜冬に長波有効放射が 比較的大きくなることから，9月中旬以降に $\alpha$ の值と変 動が特に大きくなったのはこのためと推察される。また, $E T / E T R$ が 9 月中旬以降に過大評価されたのむ, 移流 の影響に上記の影響が付加されたためと考えられる。

\section{5. 摘 要}

本研究は, (1) 日本稲水田における水面蒸発, イネ個体 群蒸散扔よび蒸発散の季節変化を明らかにするとと, (2)乙れらの簡易予測法を開発するとと，(3)日本稲と外国 稲の蒸発散特性の差異を明らかにするとと，を目的にな された。このために, 日本稲品種として「日本晴」を, 移植時期が 3 月 31 日から 7 月 5 日までの 8 作期 (N1〜 N8)で，外国稲品種として「密陽 23 号」(日印交配品 種)と「IR-36」(インド型)をN 5 亿相当する作期で栽 培した。蒸発散量掞よび水面蒸発量をミクロライシメー タで測定し, 蒸散量を両者の差加ら求めた。得られた結 果は次のように要約される。

1）生育初期に不順な天候下にあった N7 と N8 を除 けば，葉面積指数 (LAI)の小さいときの半旬平均水面 蒸発量は最大 $5 \sim 6 \mathrm{~mm} \cdot \mathrm{day}^{-1}$ 亿達した。乙れは盛夏期 の蒸発散量 $(E T)$ 亿匹敵した(Fig. 2A)。

2) LAI 最大期頃の蒸散量 $(T)$ は $E T$ の約 $90 \%$ を占 めた。

3） $E T$ 之基準蒸発散量 $(E T R)$ との比 $(E T / E T R)$ は, 各作期とも田植直後から 9 月中旬までほぼ一定值で推移 した(Fig. 2B)。このととから，日本晴の主要生育期間 の蒸発散は季節や LAI にほとんど無関係に気象条件に よって大きく支配されているてとがわかった。N4〜N8 にみられる 9 月第 4 半旬以降の $E T / E T R$ の過大評価は, 周囲加らの移流の影響による $E T$ の増加之夜間の長波有 効放射の増加によるETRの過小評価のためと推察され た。

4) 移植直後から成熟期までの蒸発散総量 $\left(\sum E T\right)$ は, $\mathrm{N} 1$ の $680 \mathrm{~mm} / 162$ day から $\mathrm{N} 8$ の $414 \mathrm{~mm} / 120$ day の 間にあった。 $\sum E T$ に占める水面蒸発総量 $\left(\sum E\right)$ の割合 は，気温が低いため初期生育期間が長びいた早い作期ほ ど大きい傾向にあった。生育全期間の日平均蒸発散量は
$4.0 \mathrm{~mm} \cdot \mathrm{day}^{-1}$ であり， 既往の研究で得られている值の 中では平均的な值であった (Table 1)。

5）外国稲 2 品種の ET/ETRにはLAI 最大期頃に弱 いピークを認めた (Fig. 4)。また $\mathrm{LAI}=2$ 以上のとき の晴天日に, $T / E T R(T$ : 蒸散量)が日本晴よりも 40 〜 $80 \%$ 大きい值を示すととがあった (Fig. 5 )。乙のとと から，インド型品種は日本稲よりも高い蒸散特性をもっ ているととが示唆された。

6）水面蒸発量と蒸散量は，既往の式と同様な（5）お よび(6)式によって推定できることがわかった。

7）蒸発散量の簡易推定法として, 日射量と気温のみ から求まる日射法 (7式)の有効性を認めた。乙れを用い て, 半旬平均蒸発散量が相関係数 $r=0.912$ で推定でき た。

8）水田蒸発散の推定を目的とした場合, PriestleyTaylor 法の適用性は劣った。乙れは，主として純放射 日量が夜間の有効放射によって大きく変動するてとに起 因するためと考えられた。

\section{謝辞}

本研究は著者らが農業技術研究所気象科 (現農業環境 技術研究所気象管理科) 在任中に行ったものである。本 研究を実施するにあたり, 当時の物理第一研究室長岩崎 尚博士には種々の御援助をいただいた。また業務科の松 本公吉, 飛田正義両技官には圈場の設定之管理に対し多 くの御協力をいただいた。ここに厚く捄礼申し上げる。

\section{引用文献}

Chapman, A. L. and Kinimonth, W. R., 1972: A water balance model for rain-grown lowland rice in northern Australia. Agric. Meteorol., $10,65-82$.

Doorenbos, J. and Pruitt, W. O., 1977: Guidlines for predicting crop water requirements. FAO Irrigation and Drainage Paper, 24, FAO, Rome, $179 \mathrm{pp}$.

Doorenbos, J. and Kassam, A. H., 1979: Yield responce to water. FAO Irrigation and Drainage Paper, 33, FAO, Rome, 193 pp.

Gunston, H. and Batchelor, C. H., 1983: A comparison of the Priestley-Taylor and Penman methods for estimating reference crop evapotranspiration in tropical countries. Agri. Water Management, 6, 65-77.

羽生寿郎・小野清治, 1960 ：寒地水田の蒸発散に関する 研究 (1), 農業気象, 16, 111-118.

堀江 武・桜谷哲夫, 1982 : 蒸発散の測定法 (I), 農業 気象, 38, 193-195.

堀江 武・桜谷哲夫, 1985 : イネの生産の気象的評価・ 予測法に関する研究，(1)個体群の吸収日射量とバイ 
オマス生産の関係，農業気象，40，331-342.

Inoue, K., Sakuratani, T. and Uchijima, Z., 1984: Stomatal resistance of rice leaves as influenced by radiation intensity and air humidity. J. Agr. Met., 40, 235-242.

岩切 敏, 1964 : 水稲植被の繁茂にとあなう水面熱収支 特性の変化について, 農業気象, $19,89-95$.

Iwakiri, S., 1965: On the evapotranspiration from paddy field in a southern part of Kyushu. J. Agr. Met., 21, 15-21.

蒸発散研究グループ, $1967 \mathrm{~A}$ : 水田の放射状態について, 農業気象，22，97-102.

蒸発散研究グループ, 1967 B : 水田の蒸発散, 農業気象, 22, 149-157.

Makkink, G. F., 1957: Ekzameno de formulo de Penman. Neth. J. Agric. Sci., 5, 290-305.

丸山幸夫・椛木信幸・田嶋公一, 1984 : 稲の水消費量, 要水量の品種間差異, 日本作物学会紀事, 53 (別 1), 78-79.

宮本硬一・日野義一, 1979 : 気候系数による水田蒸発散 量の地域性, 水温の研究, $23,35-43$.

中川慎治, 1982：蒸発散の概念とその適用性について, 筑波大学水理実験センター報告, 6, 53-62.

中山敬一・中村彰宏, 1982：Priestley-Taylor モデル による蒸発散位の推定, 農業気象, 37, 297-302.

Priestley, C. H. B. and Taylor, R. J., 1972: On the assessment of surface heat flux and evaporation using large-scale parameters. Mon. Weather Rev., 100, 81-92.

Pruitt, W. O. and Doorenbos, J., 1977: Empirical calibration, a requisite for evapotranspiration formulae based on daily or longer mean climatic data. (Burman, R. D. et al., Techniques for estimating irrigation water requirements. In: Advances in Irrigation Vol. 2, ed. D. Hillel, Academic Press, New York, 365 に引用 ).

佐藤正一, 1960 : 本邦暖地の稲作気候と水田微気候なら びに微気候調節に関する研究, 九州農試㕠報， 6 ,
$259-364$.

Seo, T. and Yamaguchi, N., 1968: A note on the evapotranspiration from a paddy field. Berichte. des Ohara Inst. Okayama Univ., 14, 133-144.

Shih, S. F., Rahi, G. S., Snyder, G. H., Harrison, D. S. and Smajstrla, A. G., 1983: Rice yield, biomass, and leaf area related to evapotranspiration. TRANSACTIONS of the ASAE, 26, 1458-1464.

Stewart, J. B., 1983: A discussion of the relationships between the principal forms of the combination equation for estimating crop evaporation. Agric. Meteorol., 30, 111-127.

Sugimoto, K., 1971: Relationship between evapotranspiration and dry matter production of Indica rice. Tech. Bull. TARC, 1, 1-80.

杉本勝男, 1973 : インド型と日本型水稲の蒸散量と要水 量に関する研究, 第 1 垠 蒸散之葉面積, 気象要因と の関係，熱帯農業，16，260-264.

杉本勝男, 1975 : インド型水稲の蒸発散に関する作物学 的研究, 第 1 報 蒸散と乾物生産の推移の関係, 熱帯 農業, 18, 131-135.

Tomar, V. S. and O'Toole, J. C., 1979: Evapotranspiration from rice fields. .IRPS, 34, 1-15.

Tomar, V. S. and O'Toole, J. C., 1980A: Measurements of evapotranspiration in rice. In: Proc. Symp. of the Agrometeorology of the Rice Crop. WMO and IRRI, 87-93.

Tomar, V. S. and O'Toole, J. C., 1980B: Water use in lowland rice cultivation in Asia: A review of evapotranspiration. Agri. Water Management, 3, 83-106.

Uchijima, Z., 1961: On characteristics of heat balance of water layer under paddy plant cover. Bull. Nat. Inst. Agr. Sci., A8, 243-265.

矢野友久・長 智男・林 泰弘, 1977 : 砂丘地に打ける 蒸発散について, 一一般気象観測資料による蒸発散位 の推定一, 鳥取大砂丘研報, 16, 1-7.

\section{Summary}

The problems are whether evapotranspiration (ET) from paddy field would be affected by growth stage and by rice varieties, and whether the radiation method and Priestley-Taylor method for estimating $E T$ would be applicable to paddy field.

$E T$ was measured with microlysimeter (Tomar and O'Toole, 1980A) at the eight test plots (N1-N8) in which cultivar "Nipponbare" (Japonica rice) was grown under eight different cropping seasons, and at the two plots (K5 and R5) in which cultivars "Milyang 23" (Japonica-Indica cross variety) and "IR-36" (Indica rice) were grown under the ordinary cropping season (see Horie and Sakuratani, 1985, Table 1). Three stainless pans $(30 \mathrm{~cm}$ long, $20 \mathrm{~cm}$ wide and $60 \mathrm{~cm}$ deep) were installed in the center part of the each plot: the two with the hills of rice plant and the other without crop were used as evapotranspirometer and evaporimeter, respectively. ET and transpiration $(T)$ from each plot were determined, respectively, by averaging the values of ET from the two pans, and 
by subtracting the evaporation $(E)$ from the $E T$. Meteorological data were also collected.

In each cropping season of "Nipponbare" rice, the $E$ at the early growth stage in which the leaf area index (LAI) was small, was comparable to the ET at the maximum LAI stage (Fig. 2A). Thus, there was no appreciable difference in ET between the two stages. This also caused the noticeable increase of total $E$ for entire growing periods in the plots of the earlier cropping seasons such as N1 and N2 in which the initial growth was delayed by lower air temperature (Table 1). The mean value of daily $E T$ ranged between 3.5 and $4.2 \mathrm{~mm} \mathrm{day}^{-1}$ for the eight cropping seasons, averaging $4.0 \mathrm{~mm} \mathrm{day}^{-1}$.

The ratio of $E T$ to reference $E T$ (ETR) calculated from modified Penman method (Doorenbos and Pruitt, 1977) was fairly constant throughout the main growth period except mid-September to October and averaged 1.05 for all the cropping season (Fig. 2B). The overestimate in the ET in the fall seemed to be owing to the enrichment of $E T$ by advective energy and to the underestimate in the ETR. On the other hand, the ET/ETR for "Milyang 23" and "IR-36" tended to increase slightly around the heading stage (Fig. 4). These varieties also tended to show higher $T$ than "Nipponbare" under the LAI above 2.0 and high radiation conditions (Fig. 5). These results suggested that crop factor such as canopy resistance is somewhat important in controlling $E T$ of Indica type rice, whereas not so important for Japonica rice.

The variation of the daily value of $a$ in the radiation method (Eq. 7) was relatively small throughout the main growth period (Fig. 6). The linear regression technique for all the cropping seasons yielded $a=0.88$, and five-day $E T$ was estimated with high correlation coefficient $(r=0.912)$.

The daily value of $\alpha$ in Priestley-Taylor method (Eq. 8) greatly fluctuated over the growing season (Fig. 6). Apparently, this variation of $\alpha$ was attributed to that of daily net radiation caused by long wave radiation exchange at nighttime. Priestley-Taylor method seemed to be less effective in estimating $E T$ of paddy field in Japan when daily values of net radiation are used. 